\title{
Analisis Pola Pembelian Produk Pada E-Commerce Panenmart
}

\section{Analysis Of Product Purchase On Panenmart E-Commerce}

\author{
Tsalis Kurniawan Husain ${ }^{1 *}$, Farizah Dhaifina Amran² \\ ${ }^{1}$ Universitas Muslim Indonesia \\ ${ }^{2}$ Universitas Muslim Indonesia \\ *E-mail : tsalis.kurniawan@umi.ac.id
}

\begin{abstract}
The purpose of this study was to determine and analyze the purchase patterns of products on Panenmart e-commerce. The basic method used is the experimental method. The sampling technique in this study is saturation sampling. The data used in the study were sourced from secondary data obtained from shopping transaction data of the sales transaction database on the website and the Panenmart's mobile application. To determine the pattern of product purchase association rules, Market Basket Analysis (MBA) is used based on three metrics, namely support, confidence and lift ratio. This study used a minimum value of support of 0.1 and a minimum value of confidence of 0.3. The results showed 3 patterns of product purchase association rules that have a strong and valid relationship to be purchased simultaneously because they had a confidence value of more than 0.3 and lift ratio value > 1 . The product items had a rule pattern namely, cayenne pepper $\rightarrow$ green bean, corn $\rightarrow$ spinach, and spinach $\rightarrow$ green bean.
\end{abstract}

Keywords: agriculture e-commmerce, market basket analysis, Panenmart

Disubmit : 22 Mei 2020; Diterima: 26 Juni 2020; Disetujui : 27 Oktober 2020

\section{PENDAHULUAN}

Pertanian di era revolusi 4.0 seharusnya memanfaatkan momentum ini untuk memanfaatkan perkembangan teknologi dan informasi dalam rangka akselerasi pembangunan pertanian yang berkelanjutan. Salah satu hal yang mungkin untuk dilakukan adalah memanfaatkan internet sebagai sumber daya baru pada aktivitas bisnis/usaha di bidang pertanian. Pranata \& Darma (2014) berpendapat bahwa Internet menawarkan peluang untuk melakukan penjualan produk kebutuhan hidup sehari-hari secara langsung kepada pelanggan yang berada pada pasar konsumsi (consumer market) atau konsumen pada pasar. Penjualan barang dan jasa secara langsung (direct selling) melalui internet dinamakan dengan istilah 'electronic commerce' atau biasanya disebut dengan istilah e-commerce. E-Commerce tidak hanya digunakan sebagai etalase produk, namun dapat digunakan dalam merancang strategi bisnis yang berbasis data.

Usaha yang berbasis e-commerce tentunya akan dimudahkan dalam pengumpulan data dan informasi karena sistemnya mampu merekam setiap aktivitas yang terjadi pada platformnya. Hal ini sejalan dengan pendapat Kamakura (2012) dan Irmawati (2011) yang menjelaskan e-commerce lebih dimudahkan dalam proses pengumpulan data karena dilakukan secara otomatis sehingga bermanfaat dalam membangun database pelanggan yang komprehensif. Produsen dapat mempunyai informasi tentang pola pemesanan yang dilakukan pelanggan dan mengelolanya sebagai informasi yang berharga. Database tersebut akan membantu 
produsen saat melakukan pemasaran dan strategi promosi agar dapat tepat sasaran. Selanjutnya Ariana \& Asana (2013) dan Prasidya \& Fibriani (2017) menambahkan bahwa dengan mengetahui informasi kebiasaan belanja pelanggan pihak perusahaan dapat melakukan beberapa tindakan untuk meningkatkan penjualan dengan mengacu pada kombinasi item yang sering dibeli secara bersamaan. Contoh tindakan yang dapat dilakukan seperti promosi harga untuk barang yang berpasangan, mengatur letak barang yang sering dibeli secara bersamaan pada satu rak, dan melakukan pengadaan stok barang yang lebih tepat guna dengan melakukan pengadaan stok barang yang berimbang pada item-item yang sering dibeli secara bersamaan.

Panenmart merupakan e-commerce yang bergerak di bidang pertanian dimana aktivitas bisnisnya adalah menawarkan hasil panen petani secara direct selling ke konsumen akhir. Kebutuhan konsumen akan sayur-sayuran, buah-buahan, bumbu dapur dan produk olahan sehat bisa dipenuhi hanya dengan melakukan pemesanan melalui website www.panenmart.com atau bisa mengorder langsung melalui aplikasi mobile panenmart. Panenmart yang berdiri sejak 2016 tentunya memiliki banyak data dan informasi terkait aktivitas bisnisnya. Salah satu informasi atau data yang terekam dengan baik adalah data transaksi pembelian produk oleh konsumen melalui website dan aplikasi mobile, namun sejauh ini data tersebut belum termanfaatkan dengan baik untuk diolah sehingga menjadi informasi yang bermanfaat bagi perusahaan.

Ketersediaan detail informasi transaksi pelanggan mendorong pengembangan teknik yang secara otomatis mencari hubungan antaraitem dalam data di database. Database penjualan menyimpan jumlah record transaksi penjualan yang sangat besar. Setiap record memberikan daftar item barang yang dibeli oleh pelanggan dalam satu transaksi (Badrul, 2016). Berdasarkan informasi, data dan fenomena yang telah dipaparkan, maka peneliti tertarik untuk melakukan penelitian mengenai analisis pola pembelian produk pada e-commerce Panenmart.

\section{METODE PENELITIAN}

Pelaksanaan penelitian menggunakan teknik penelitian eksperimen. Lokasi penelitian dipilih secara sengaja (purposive) yaitu Panenmart yang berada di Kota Makassar dengan pertimbangan bahwa perusahaan tersebut merupakan e-commerce yang memasarkan produk-produk pertanian melalui website dan aplikasi mobile. Populasi dalam penelitian ini seluruh transaksi belanja Panenmart melalui website dan aplikasi mobile pada tahun 2019. Teknik pengambilan sampel pada penelitian ini adalah sampling jenuh (sensus). Data yang digunakan dalam penelitian bersumber dari data sekunder yang diperoleh dari data transaksi belanja yang didapatkan melalui database transaksi penjualan website dan aplikasi mobile Panenmart.

Untuk mengetahui pola aturan asosiasi pembelian produk maka digunakan Market Basket Analysis (MBA). Catatan transaksi penjualan Panenmart selanjutnya dianalisis dengan MBA berdasarkan tiga metrik, yaitu support, confidence dan lift ratio. Adapun penjelasan ketiga metrik ini sebagai berikut (Dewantara, et al., 2018; Ghozali, et al., 2017)

Metrik pertama ditetapkan untuk analisis keranjang pasar adalah nilai support, yang merupakan probabilitas dari asosiasi (probabilitas dari dua item yang dibeli bersama-sama). Tahap ini biasa disebut sebagai pola frekuensi tinggi untuk mencari kombinasi item yang memenuhi syarat minimum dari nilai support dalam database. Nilai support sebuah Item diperoleh dengan rumus berikut.

$$
\text { Support }(A)=\frac{\text { Jumlahtransaksi mengandung } A}{\text { total transaksi }}
$$

Sementara itu, nilai support dihasilkan dari berapa kali jumlah item A dan B terjadi bersamaan dalam transaksi yang sama dibagi dengan jumlah total dari transaksi tersebut. Untuk menghitung nilai support dari 2 item diperoleh dari rumus sebagai berikut berikut. 


$$
\text { Support }(A, B)=\frac{\sum \text { transaski } A \text { dan } B}{\text { total transaksi }}
$$

Untuk eksperimen ditentukan nilai minimum support adalah 10\% - 100\%. Pada penelitian ini nilai minimum support ditentukan oleh peneliti sebesar 0,1 atau $10 \%$. Produk atau kombinasi produk yang tidak mencapai nilai minimum selanjutnya tidak akan dianalisis pada perhitungan metrik selanjutnya.

Tahapan kedua adalah mencari nilai confidence. Setelah semua pola frekuensi tinggi ditemukan, barulah dicari aturan asosiasi yang memenuhi syarat minimum untuk confidence. Confidence dihasilkan dari seberapa kuat hubungan produk yang sudah dibeli. Untuk menghitung confidence aturan asosiatif $\mathrm{A} \rightarrow \mathrm{B}$. Nilai confidence dari aturan $\mathrm{A} \rightarrow \mathrm{B}$. diperoleh dari rumus berikut.

$$
\text { confidence }=P(A B \mid A)=\frac{\sum \text { transaksi mengandung } A \text { dan } B}{\sum \text { transaksimengandung } A}
$$

Untuk eksperimen ditentukan nilai Minimum Confidence adalah 10\% - 100\%. Pada penelitian ini nilai minimum confidence ditentukan oleh peneliti sebesar 0,3 atau 30\%. Produk atau kombinasi produk yang tidak mencapai nilai minimum selanjutnya tidak akan dianalisis pada perhitungan metrik selanjutnya.

Tahap ketiga dalam pencarian nilai lift ratio. Lift Ratio mengukur seberapa penting rule yang telah terbentuk berdasarkan nilai support dan confidence. Lift Ratio merupakan nilai yang menunjukkan kevalidan proses transaksi dan memberikan informasi apakah benar produk A dibeli bersamaan dengan produk B. Untuk menghitung nilai Lift Ratio digunakan persamaan sebagai berikut.

$$
\text { Lift ratıo }=\frac{\text { Support } A \cap B}{\text { Support }(A) \times \operatorname{Support}(B)}
$$

Sebuah transaksi dikatakan valid jika mempunyai nilai Lift Ratio lebih dari 1, yang berarti bahwa dalam transaksi tersebut, produk A dan B benar-benar dibeli secara bersamaan. Lift Ratio mengukur seberapa penting rule yang telah terbentuk berdasarkan nilai support dan confidence.

\section{HASIL DAN PEMBAHASAN}

Perusahaan Panenmart melakukan proses pengadaan langsung dari petani yang dimana perusahaan telah bekerjasama dengan petani pemasok. Kemudian dilakukan proses sortasi dan grading. Setelah dilakukan proses sortasi dan grading kemudian dibawa ke gudang untuk proses penyimpanan dan pengemasan. Setelah semua produk sampai di gudang kemudian dilakukan pendataan produk yang kemudian akan ditampilkan pada website penjualan www.panenmart.com untuk dipasarkan. Setelah mendapat order dan melakukan transaksi pembayaran, kemudian kembali dilakukan pengemasan pada gudang untuk diantarkan melalui kurir hingga sampai ke konsumen (Adisti et al., 2019). Kelebihan dari model bisnis Panenmart yaitu mampu menunjukkan ketersediaan jumlah stok barang sehingga memudahkan pelanggan dalam melakukan keputusan pembelian, di mana menurut Sutarni et al. (2019) informasi ketersediaan sayur merupakan faktor penting bagi konsumen dalam melakukan keputusan pembelian.

Panenmart sebagai perusahaan yang berbasis digital, cukup mudah untuk merekam setiap aktivitas jual belinya. Konsumen yang ingin melakukan pembelian cukup memilih sayur, buah, bumbu dapur atau produk olahan lainnya ke dalam keranjang belanja digital dan selanjutnya melakukan pembayaran. Setiap transaksi yang berhasil otomatis akan tercatat di database perusahaan sebagai data pembelian produk oleh konsumen. Data pembelian produk ini selanjutnya dikumpulkan, diolah dan dianalisis untuk menggambarkan pola pembelian produk yang berguna untuk strategi persediaan dan pemasaran perusahaan.

Data yang digunakan dalam penelitian ini adalah semua data transaksi pembelian tahun 2019, dimana pada tahun tersebut Panenmart mencatatkan 147 transaksi dengan 54 jenis varian produk. Data-data ini selanjutnya diolah dan dianalisis untuk melihat pola aturan asosiasi pembelian produk dengan menggunakan tiga metrik, yaitu nilai support, nilai confidence dan nilai lift ratio. Untuk memudahkan proses analisis maka penelitian ini terbagi beberapa tahapan analisis mulai dari analisis pola pembelian 1 item produk, 2 item 
produk, 3 item produk dan seterusnya hingga tidak ada lagi kombinasi produk yang mencapai minimum nilai support dan nilai confidence.

Tahapan pertama dalam analisis ini adalah menghitung frekuensi pembelian per 1 item produk, seberapa sering produk dibeli oleh konsumen dari 147 transaksi yang tercatat. Jenis produk sebanyak 54 item kemudian disusun dari frekuensi pembelian terbesar sampai frekuensi pembelian yang terkecil yang ditunjukkan pada gambar 1 berikut. Untuk memudahkan visualisasi, gambar 1 hanya menampilkan sepuluh produk tertatas dengan frekuensi terbanyak.

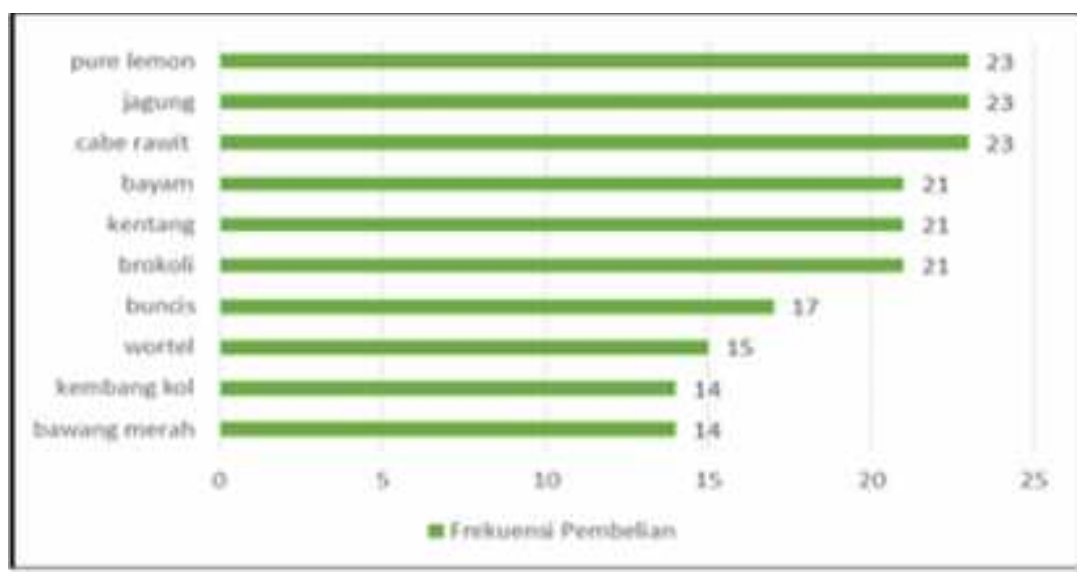

Gambar 1. Sepuluh Produk Terlaris Panenmart Tahun 2019

Gambar 1 menunjukkan item produk yang memiliki frekuensi terbanyak adalah pure lemon, jagung, dan cabe rawit dengan jumlah frekuensi sebanyak 23 kali. Dilanjutkan dengan produk bayam, kentang, dan brokoli yang memiliki frekuensi pembelian yang sama sebanyak 21 kali. Urutan berikutnya adalah buncis, wortel, kembal kol dan bawang merah, dimana masing-masing frekuensi pembeliannya sebanyak $17 \mathrm{kali}, 15$ kali, dan 14 kali untuk kembang kol dan bawang merah. Jumlah frekuensi pembelian ini selanjutnya dijadikan variabel untuk menghitung nilai support setiap item produk. Adapun hasil perhitungan nilai support ditampilkan pada tabel 1 berikut.

Tabel 1. Frekuensi dan Support 10 Item Produk Terbanyak Panenmart

\begin{tabular}{|c|c|c|}
\hline Kombinasi Produk & Frekuensi & Support \\
\hline Cabe Rawit & 23 & 0,16 \\
\hline Jagung & 23 & 0,16 \\
\hline Pure Lemon & 23 & 0,16 \\
\hline Brokoli & 21 & 0,14 \\
\hline Kentang & 21 & 0,14 \\
\hline Bayam & 21 & 0,14 \\
\hline Buncis & 17 & 0,12 \\
\hline Wortel & 15 & 0,10 \\
\hline Bawang Merah & 14 & 0,10 \\
\hline Kembang Kol & 14 & 0,10 \\
\hline
\end{tabular}

Sumber: Analisis Data Sekunder, 2020

Nilai support pada tabel 1 menunjukkan seberapa sering sebuah item produk dibeli dari total seluruh transaksi (147 transaksi). Item produk yang memiliki nilai support $\geq 0,1$ bermakna bahwa produk tersebut memiliki pola frekuensi tinggi. Tabel 1 menjelaskan bahwa 10 item teratas dengan frekuensi pembelian tertinggi memiliki nilai support $\geq 0,1$ sedangkan 44 produk lainnya memiliki nilai support $<0,1$. Produkproduk yang tidak mencapai nilai support selanjutnya tidak diperhitungkan pada tahap analisis selanjutnya. 
Produk yang mencapai minimum support pada tahap pertama, yaitu cabe rawit, jagung, pure lemon, brokoli, kentang, bayam, buncis, wortel, bawang merah dan kembang kol, selanjutnya 10 produk tersebut dicari kekuatan hubungannya dengan produk lainnya. Sepuluh item produk yang bersyarat pada tahapan sebelumnya kemudian dikombinasikan satu sama lainnya dengan pola 2 itemset produk. Hasilnya ditemukan 45 pasang produk yang selanjutnya dianalisis untuk mencari frekuensi pembelian pasangan produk, nilai support dan nilai confidencenya. Hasil analisis untuk 10 pola kombinasi 2 itemset produk terbanyak ditunjukkan pada tabel 2 berikut.

Tabel 2. Frekuensi, Support, dan Confidence 10 Kombinasi 2 Item Produk Terbanyak Panenmart

\begin{tabular}{lccc}
\hline \multicolumn{1}{c}{ Kombinasi Produk } & Frekuensi & Support & Confidence \\
\hline Cabe Rawit $\rightarrow$ Buncis & 9 & 0,1 & 0,38 \\
Jagung $\rightarrow$ Bayam & 8 & 0,1 & 0,34 \\
Bayam $\rightarrow$ Buncis & 8 & 0,1 & 0,39 \\
Brokoli $\rightarrow$ Bayam & 7 & 0,05 & 0,34 \\
Cabe Rawit $\rightarrow$ Bawang Merah & 7 & 0,05 & 0,30 \\
Cabe Rawit $\rightarrow$ Jagung & 7 & 0,05 & 0,30 \\
Kentang $\rightarrow$ Wortel & 7 & 0,05 & 0,34 \\
Kentang $\rightarrow$ Jagung & 7 & 0,05 & 0,34 \\
Kentang $\rightarrow$ Bayam & 7 & 0,05 & 0,34 \\
Brokoli $\rightarrow$ Wortel & 6 & 0,04 & 0,29 \\
\hline Sumber: Analis Data Sekunder
\end{tabular}

Sumber: Analisis Data Sekunder, 2020.

Tabel 2 menguraikan bahwa dari 45 pola kombinasi 2 itemset produk, hanya 3 kombinasi itemset saja yang mencapai nilai support minimum dengan nilai support $\geq 0,1$. Kombinasi produk tersebut adalah cabe rawit $\rightarrow$ buncis, jagung $\rightarrow$ bayam, dan bayam $\rightarrow$ buncis. Ketiga kombinasi ini selanjutnya dianalisis menggunakan metrik nilai confidence dan nilai lift ratio untuk melihat seberapa kuat hubungan antaritem terbentuk. Adapun nilai support, nilai confidence dan nilai lift ratio dari kombinasi tersebut ditunjukkan pada tabel 3.

Tabel 3. Support, Confidence, dan Lift Ratio Kombinasi 2 Item Produk yang Memenuhi Syarat Minimum

\begin{tabular}{lccc}
\hline \multicolumn{1}{c}{ Kombinasi Produk } & Support & Confidence & Lift Ratio \\
\hline Cabe Rawit $\rightarrow$ Buncis & 0,1 & 0,38 & 3,19 \\
Jagung $\rightarrow$ Bayam & 0,1 & 0,34 & 2,43 \\
Bayam $\rightarrow$ Buncis & 0,1 & 0,39 & 3,24 \\
\hline
\end{tabular}

Sumber: Analisis Data Sekunder, 2020

Tabel 3 menunjukkan bahwa ketiga kombinasi produk yang mencapai nilai support juga memiliki nilai confidence yang melebihi nilai minimum confidence yairu $\geq 0,3$. Nilai confidence dari ketiga kombinasi ini menunjukkan hubungan yang kuat antar item produk dibeli secara bersamaan pada setiap transaksi. Kombinasi produk cabe rawit $\rightarrow$ buncis, jagung $\rightarrow$ bayam, dan bayam $\rightarrow$ buncis yang memenuhi syarat metrik nilai confidence selanjutnya dianalisis menggunakan metrik nilai lift ratio untuk mengukur valid tidaknya hubungan antaritem produk. Tabel 3 mengungkapkan bahwa nilai lift ratio dari ketiga kombinasi produk > 1 yang artinya bahwa benar produk-produk dalam pola kombinasi 2 itemset produk sering dibeli secara bersamaan.

Adapun aturan asosiasi yang terbentuk dari 2 itemset produk adalah sebagai berikut: (1) Cabe Rawit $\rightarrow$ Buncis; Jika membeli cabe rawit maka membeli buncis dengan nilai confidence 0,38 yang artinya bahwa $38 \%$ dari seluruh konsumen yang membeli cabe rawit juga membeli buncis. (2) Jagung $\rightarrow$ Bayam; Jika membeli jagung maka membeli bayam dengan nilai confidence 0,34 yang artinya bahwa $34 \%$ dari seluruh konsumen yang membeli jagung juga membeli bayam. (3) Bayam $\rightarrow$ Buncis; Jika membeli bayam maka membeli buncis dengan nilai confidence 0,39 yang artinya bahwa 39\% dari seluruh konsumen yang membeli bayam juga membeli buncis. Semua produk yang membentuk kombinasi yang valid tersebut merupakan produk dengan kategori sayur-sayuran pada tampilan e-commerce Panenmart. Jenis sayuran yang 
membentuk kombinasi yang valid merupakan kombinasi sayur yang cenderung sering diolah secara bersama dalam satu menu masakan.

Seluruh item produk yang terdapat pada pola kombinasi 2 itemset produk yang memenuhi syarat nilai minimum support dan nilai confidence selanjutnya dikombinasikan untuk membuat pola kombinasi 3 itemset produk. Paket 3 itemset produk yang terbentuk hanya 4 pola kombinasi yang ditunjukkan ada tabel 4 berikut. Tabel 4. Kombinasi 3 Item Produk Panenmart

\begin{tabular}{lcc}
\multicolumn{1}{c}{ Kombinasi Produk } & Frekuensi & Support \\
\hline Jagung, Bayam $\rightarrow$ Buncis & 3 & 0,02 \\
Cabe Rawir, Bayam $\rightarrow$ Buncis & 4 & 0,03 \\
Cabe Rawit, Jagung $\rightarrow$ Bayam & 4 & 0,03 \\
Cabe Rawit, Jagung $\rightarrow$ Buncis & 4 & 0,03 \\
\hline
\end{tabular}

Sumber: Analisis Data Sekunder, 2020

Tabel 4 menunjukkan dari semua pola kombinasi 3 itemset produk, tidak ada yang mencapai minimum nilai support sehingga analisis tidak dilanjutkan ke tahap selanjutnya untuk menghitung nilai confidence dan nilai lift ratio ataupun membentuk pola kombinasi 4 itemset produk dan seterusnya.

\section{KESIMPULAN DAN SARAN}

Temuan dalam penelitian ini adalah pola pembelian produk oleh konsumen yang membentuk aturan asosiasi antaritem yang kuat adalah cabe rawit dan buncis; jagung dan bayam; serta bayam dan buncis. Semua kombinasi 2 itemset produk tersebut memiliki hubungan yang erat dan valid dibeli secara bersamaan. Adapun item produk yang memiliki frekuensi pembelian terbanyak oleh konsumen adalah pure lemon, jagung dan cabe rawit.

Adapun yang menjadi saran dalam penelitian ini adalah untuk e-commerce Panenmat sebaiknya mengatur manajemen stock produk, membuat paket spesial dengan 2 itemset produk yang memiliki hubungan yang kuat, serta menempatkan secara berdekatan produk-produk yang memiliki asosiasi yang erat dalam interface website atau aplikasi mobilenya sehingga bisa menstimulus peningkatan penjualan.

\section{DAFTAR PUSTAKA}

Ariana, A. G. B., \& Asana, I. M. D. P .(2013). Analisis Keranjang Belanja Dengan Algoritma Apriori Pada Perusahaan Retail', Seminar Nasional Sistem Informasi Indonesia (hal 522-527). 2-4 Desember 2013. Surabaya:ITS.

Adisti, A. et al. (2019) 'Panen Mart' s Existence in using Marketing Communication Strategies of Selling Agriculture Products', 13(12), pp. 43-50. doi: 10.22587/aeb.2019.13.12.8.

Badrul, M. (2016). Algoritma Asosiasi dengan Algoritma Apriori untuk Analisa Data Penjualan. Jurnal Pilar Nusa Mandiri. 12(2), 121-129.

Pranata, M. A. K. I. \& Darma, G. S.(2014). Strategi Penerapan E-Commerce dalam Meningkatkan Keunggulan Bersaing. Jurnal Manajemen dan Bisnis, 11(1), 69-81.

Dewantara, H., Santosa, P. B. and Setyanto, N. W. (2018). Perancangan Aplikasi Data Mining dengan Algoritma Apriori untuk Frekuensi Analisis Keranjang Belanja pada Data Transaksi Penjualan (Studi Kasus di Swalayan KPRI Universitas Brawijaya). Jurnal Rekayasa dan Manajemen Sistem Industri, 1(3). 415-426.

Ghozali, M. I., Ehwan, R. Z. and Sugiharto, W. H. (2017). Analisa Pola Belanja Menggunakan Algoritma FP Growth, Self Organizing Map (SOM) dan K Medoids. Simetris: Jurnal Teknik Mesin, Elektro dan Ilmu Komputer. 8(1), 317-326. doi: 10.24176/simet.v8i1.995. 
Irmawati, D. (2011). Pemanfaatan E-Commerce dalam Dunia Bisnis. Jurnal Ilmiah Orasi Bisnis, (4), 95112

Kamakura, W. A. (2012). Sequential Market Basket Analysis. Marketing Letters. 23(3), 505-516. doi: 10.1007/s11002-012-9181-6.

Prasidya, A. K. \& Fibriani, C. (2017). Analisis Kaidah Asosiasi Antar Item dalam Transaksi Pembelian Menggunakan Data Mining dengan Algoritma Apriori (Studi Kasus: Minimarket Gun Bandungan, Jawa Tengah). JUTI: Jurnal Ilmiah Teknologi Informasi. 15(2), 173-184. doi: 10.12962/j24068535.v15i2.a629.

Sutarni, S., Irawati, L., Unteawati, B., \& Yolandika, C. (2019). Proses Pengambilan Keputusan Pembelian Sayuran Hidroponik di Kota Bandar Lampung. Journal of Food System \& Agribusiness. 2 (1). 17-24 doi: 10.25181/jofsa.v2i1.1107. 